\title{
Effect of Fluoride Solutions on the Shear Bond Strength of Orthodontic Brackets
}

\author{
Gabriela da Rocha LEÓDIDO ${ }^{1}$ \\ Hianna Oliveira FERNANDES ${ }^{1}$ \\ Mateus Rodrigues TONETTO ${ }^{2}$ \\ Cristina Dupim PRESOTO ${ }^{2}$ \\ Matheus Coêlho BANDÉCA ${ }^{1}$ \\ Leily Macedo FIROOZMAND ${ }^{1}$ \\ ${ }^{1}$ Department of Restorative Dentistry, Dental School, CEUMA - Maranhão University Center, São Luis, MA, Brazil \\ ${ }^{2}$ Department of Restorative Dentistry, Araraquara Dental School, \\ UNESP - Univ Estadual Paulista, Araraquara, SP, Brazil
}

\begin{abstract}
The aim of this in vitro study was to evaluate the shear bond strength of brackets after pre-treatment with different fluoride solutions. This study used 48 freshly extracted sound bovine incisors that were randomly assigned to 4 experimental groups ( $\mathrm{n}=12)$. CG: (control) without treatment; NF: 4 min application of neutral fluoride; APF: application of $1.23 \%$ acidulated phosphate fluoride (APF) for 4 min; and SFV: application of 5\% sodium fluoride varnish for $6 \mathrm{~h}$. For each group, after surface treatment, prophylaxis of enamel and bracket bonding with Transbond XT composite resin $(3 \mathrm{M})$ were performed following the manufacturer's specifications. The shear bond strength was performed with a universal testing machine $24 \mathrm{~h}$ after fixing the brackets. The tooth surfaces were analyzed to verify the adhesive remnant index (ARI). Data were analyzed statistically by ANOVA and Tukey's test $(\alpha=0.05)$. There was statistically significant difference among the groups $(\mathrm{p}<0.0001)$. CG and NF groups presented significantly higher bond strength than APF and SFV. There was no significant difference between CG and NF or between APF and SFV ( $p>0.05)$. The analysis of ARI scores revealed that most failures occurred at the enamel-resin interface. It may be concluded that the pre-treatment of enamel with $1.23 \%$ APF and 5\% SFV prior to fixing orthodontic brackets reduces shear bond strength values.
\end{abstract}

Key Words: acidulated phosphate fluoride, orthodontic brackets, shear strength.

\section{INTRODUCTION}

Fluoride is an important adjuvant in the prevention and treatment of initial caries lesions and its use is indicated in different phases of dental treatment. The formation of white lesions of caries around orthodontic brackets is identified as a common complication found in patients with poor oral hygiene (1).

Fluoride gel and sodium fluoride varnish at different concentrations can be used with efficacy and safety for the remineralization of dental structure and to prevent the development of initial caries lesions (2-4). The presentation forms of fluoride in acidified solutions increase the absorption to enamel surface, resulting in greater benefits to the tooth (5). However, sodium fluoride varnishes are able to promote a greater cariostatic effect when compared with acidulated phosphate fluoride gels (APF, 1.23\%) (6), reducing enamel demineralization adjacent to orthodontic brackets (7). Among the available fluoride solutions, different concentrations and formulations have different effects on enamel $(5,8)$.

In clinical orthodontics, it is essential to establish a reliable bond strength between enamel and orthodontic appliances. Thus, in vitro studies demonstrate that the use of prophylactic agents with different fluoride concentrations do not significantly affect the adhesion of orthodontic brackets $(9,10)$.

However, studies are needed to evaluate the influence of topical fluoride application on shear bond strength because the mechanism of action of fluoride is a chemical reaction of these solutions with the tooth 
structure. The cariostatic effect occurs due to the formation of a calcium fluoride layer $\left(\mathrm{CaF}_{2}\right)$ which dissolves and releases ions by $\mathrm{pH}$ reduction to prevent that the underlying enamel is reached (11). APF $1.23 \%$ has a $\mathrm{pH}$ of 3.2-3.5, in which a low concentration of hydrogen dissolves the enamel surface to form $\mathrm{CaF}_{2}$. The application of APF induces fluoride deposition in hydroxyapatite and formation of fluorapatite, which can affect the bond strength (12).

Immediate fixing of orthodontic brackets after a previous application of fluoride agents needs evaluation. Choi et al. (13) recommend that in restorative procedures etching of enamel should be done after 2 weeks of treatment with APF. Scanning electron microscopy and atomic force microscopy showed that pretreatment with APF decreases the formation of microporosity in the enamel of primary and permanent teeth.

Studies that evaluate the interference of the application of topical fluoride solutions performed in the same session in which occurs bonding of brackets are still very scarce, since the majority of studies evaluate the fluoride solutions incorporated into toothpastes, dental materials or even the use of these solutions days before bonding of orthodontic attachments (14).

The purpose of this study was to evaluate the shear bond strength between orthodontic brackets and dental enamel after the treatment with acidulated phosphate fluoride, neutral fluoride and 5\% sodium fluoride varnish applied immediately prior to bonding procedures. The null hypotheses tested were that there is no significant difference in the bond strength of brackets after enamel pretreatment with different fluoride solutions.

\section{MATERIAL AND METHODS}

A random sample of 48 freshly extracted bovine incisors was selected. The teeth were frozen in distilled water until use. This research project was approved by the Ethics Comitte of Research and Animals of State University of Maranhão (UEMA), Brasil. The criteria for tooth selection were: intact enamel, with no cracks and no prior use of chemical agents such as thymol, hydrogen peroxide, alcohol or formaldehyde.

The bovine roots were sectioned at the coronal third with a carborundum disk and discarded. Then the coronal pulp was excised with a dentin curette (Duflex Lucas number 86; SSWhite, Rio de Janeiro, RJ, Brazil), irrigated with distilled water, dried with short air blasts and sealed with utility wax (Epoxiglass Ind, Diadema,
SP, Brazil) to avoid penetration of the acrylic resin used for inclusion. After preparation, the crowns were placed inside $25 \times 20 \mathrm{~mm}$ PVC cylinders and embedded in acrylic resin (Dental VIPI Ltda., Pirassununga, SP, Brazil) with the buccal surface parallel to the cylinder.

The specimens were stored in artificial saliva for $24 \mathrm{~h}$ and randomly assigned to 4 groups $(\mathrm{n}=12)$. In CG (control), the specimens were stored in distilled water for $24 \mathrm{~h}$ before bracket fixation. In the experimental groups, enamel surface was treated prior to fixation of brackets as follows: NF: 4 min application of a neutral fluoride gel (Flugel; DFL Industria e Comércio S.A., Rio de Janeiro, RJ, Brazil) on enamel prior to bracket fixation; APF: application of a $1.23 \%$ acidulated phosphate fluoride gel (Fluorsul; Idontosul, Porto Alegre, RS, Brazil) for 4 min (3); and SFV: application of 5\% sodium fluoride varnish (Duraphat; Colgate-Palmolive, São Paulo, SP, Brazil) for $6 \mathrm{~h}$. After application of the fluoride solutions, all specimens were washed in saliva.

Stainless steel orthodontic brackets for maxillary central incisors with base $1.5 \mathrm{~mm}$ high $\mathrm{x} 4.0 \mathrm{~mm}$ wide (Roth 0.022" x 0.030"; Kirium Abzil Indústria e Comércio Ltda., São José do Rio Preto, SP, Brazil) were fixed immediately after treatment of the specimens with fluoride solutions. In the control group, although not submitted to fluoride treatment, the orthodontic brackets were fixed after a time interval equivalent to the other groups.

Prior to the bonding of brackets, prophylaxis of the buccal surface was performed using a Robson brush and extra-fine water-based pumice paste without fluoride for $10 \mathrm{~s}$. On the buccal surface was applied 37\% phosphoric acid gel (FGM Dental Products, Joinville, $\mathrm{SC}$, Brazil) for $30 \mathrm{~s}$, rinsing with water for the same period and drying with compressed air. Afterwards, the adhesive system Transbond ${ }^{\mathrm{TM}}$ XT Ligth Cure Adhesive (3M Unitek Orthodontic Products, Monrovia, CA, USA) was applied and light cured for $20 \mathrm{~s}$ with ta LED unit (Optilight; Gnatus, Ribeirão Preto, SP, Brazil) with light intensity greater than $500 \mathrm{~mW} / \mathrm{cm}^{2}$, measured by a curing radiometer (Gnatus) and wavelength in the range between 450 and $480 \mathrm{~nm}$. The brackets were positioned with Transbond ${ }^{\mathrm{TM}} \mathrm{XT}$ composite resin and light-cured for $20 \mathrm{~s}$ on each surface (distal and mesial). Maximum pressure was used during bonding of the brackets, standardizing the strength exerted and film thickness of resin. Before polymerization, excesses were removed with an explorer (Duflex; SS White, Rio de Janeiro, RJ, Brazil). The procedures were performed by a single 
trained and calibrated operator.

The specimens were incubated in an incubator at $37^{\circ} \mathrm{C}$ for $24 \mathrm{~h}$. After this, shear bond strength was performed using a universal testing machine with $50 \mathrm{~kg}$ load applied on the buccal surface, close to the enamel/ adhesive interface at a $0.5 \mathrm{~mm} / \mathrm{min}$ crosshead speed until fracture of the specimens. The force required to remove the attachments was measured in $\mathrm{N}$ and shear bond strength in MPa. The bond strength results were obtained with the aid of a computer program (TESC) connected to the universal testing machine. After shearing, the enamel surfaces were analyzed according to the scores proposed by Artun and Bergland (15) (Table 1) in order to determine the adhesive remnant index (ARI).

Data were analyzed by one-way ANOVA and Tukey's post hoc test $(\alpha=0.05)$ using PASW Statistics (version 18; SPSS Inc., Chicago, IL, USA) and GraphPad Prism 5, 2007 (GraphPad Prism Inc., San Diego, CA, USA).

\section{RESULTS}

The descriptive statistics for the bond strength in the different experimental groups are presented in Table 2 , as well as the minimum and maximum values in the different groups. One-way ANOVA showed statistically significant differences among the groups treated with fluoride solutions $(\mathrm{F}=12.90, \mathrm{p}=0.0001)$. $\mathrm{CG}$ and $\mathrm{NF}$ groups had significantly higher bond strengths than the other groups.

ARI analysis revealed a predominance of failures at the enamel-resin interface (Table 3).

\section{DISCUSSION}

The null hypothesis was rejected because the different fluoride solution applied on sound enamel before bonding the brackets promoted a decrease in the

Table 2. Means (standard deviations), minimum and maximum bond strength values.

\begin{tabular}{lccc}
\hline Group $(\mathrm{n}=12)$ & Mean (sd) & Max & Min \\
\hline Control & $13.80(1.62)^{\mathrm{a}}$ & 18.18 & 12.34 \\
Neutral fluoride & $11.42(1.96)^{\mathrm{a}}$ & 10.86 & 1.14 \\
$1.23 \% \mathrm{APF}$ & $8.68(1.53)^{\mathrm{b}}$ & 10.73 & 6.21 \\
$5 \% \mathrm{NaF}$ varnish & $8.56(3.78)^{\mathrm{b}}$ & 15.41 & 4.57 \\
\hline
\end{tabular}

In vitro studies assessing the interference of topical use of fluoride solutions on the shear bond strength of orthodontic devices refer to the use of fluoride incorporated into prophylactic pastes $(9,10)$ related to restorative materials (14) or even on the enamel that underwent severe changes in $\mathrm{pH}$. However, there is a lack of studies that evaluate the effect of fluoride solutions at high and low concentration on sound enamel, applied prior to bonding the brackets.

Prophylaxis for 10 to $15 \mathrm{~s}$ with brushes prior to bonding procedures, as performed in this study may be able to reduce $10 \mu \mathrm{m}$ of enamel (16). This procedure increases the surface energy, which favors the adhesion. However, topical application of fluoride solutions may decrease the surface energy, reducing the spreading ability of the adhesive.

The application of fluoride solutions on sound enamel is characterized as a preventive approach, as in patients with poor oral hygiene, in which fluoride can act as a preventive agent for reducing the incidence of caries (17).

Fluoride promotes the formation of fluorapatite in enamel, which is considered less soluble than hydroxyapatite. Teeth with high fluoride concentrations are generally considered more resistant to etching and may require more conditioning time. Teeth with fluorosis, however, show a decrease in the bond strength of orthodontic brackets when compared with normal

Table 1. Adhesive remnant index (ARI).

\begin{tabular}{lr}
\hline Scores & Adhesive Remnant Index \\
\hline 0 & No adhesive remained on enamel \\
1 & Less than $50 \%$ of the adhesive remained on enamel \\
2 & More than $50 \%$ of the adhesive remained on enamel \\
3 & All adhesive remained on enamel \\
\hline
\end{tabular}

Table 3. Distribution of adhesive remnant index (ARI).

\begin{tabular}{lcccc}
\hline \multirow{2}{*}{ Group $(\mathrm{n}=12)$} & \multicolumn{4}{c}{ ARI scores (\%) } \\
\cline { 2 - 5 } & 0 & 1 & 2 & 3 \\
\hline Control & $4(33.2)$ & $7(58.4)$ & $1(8.4)$ & 0 \\
Neutral fluoride & $8(66.6)$ & $3(25)$ & $1(8.4)$ & 0 \\
$1.23 \%$ APF & $10(83.2)$ & $1(8.4)$ & $1(8.4)$ & 0 \\
$5 \% \mathrm{NaF}$ varnish & $2(16.6)$ & $7(58.4)$ & $1(8.4)$ & $2(16.6)$ \\
\hline
\end{tabular}


enamel (18). While some studies have shown that fluoride or fluoridated dentifrices do not seem to affect the bonding strength (19), the action of fluoride on the enamel should be considered because previous studies used different methodologies. It is also known that the bond strength tests are performed after 7 and 10 days of topical fluoride application, which would not change the bonding strength of brackets (19).

Bonding of brackets immediately after topical application of fluoride solutions was not found in the literature. In the present study, significant differences in bond strength were found when $1.23 \% \mathrm{APF}$ and $5 \% \mathrm{SFV}$ were applied, but NF application showed no statistically significant difference.

It is suggested that a mixture of phosphoric acid with an APF gel minimizes the loss of enamel during the acid attack, not necessarily compromising the adhesive bond strength of the orthodontic bracket (20). However, these findings are not unanimous in the literature, since Meng et al. (21) found that APF application after etching reduced the bond strength of brackets to enamel.

In this study, the resinous material adhesion was found to be influenced by the type of fluoride solution. Considering the benefits of the materials that release fluoride, the resin-modified glass ionomer cements when used without previous application of fluoride have higher bond strength than when the fluoride solution is applied before fixing the brackets. Evaluating the application of self-etch or etch-and-rinse adhesives (19), it was suggested that sodium fluoride varnish does not affect significantly the bond strength of orthodontic brackets when bonded after 10 days of storage in saliva. The literature also reports that different brands of sodium fluoride varnish may provide different results when applied in the same experimental conditions (19).

With the exception of the control group, the values obtained were below $12.41 \mathrm{MPa}$, which is suggested by Bishara et al. (22) as being safe for enamel integrity. Adhesive forces between 5.9 to $7.8 \mathrm{MPa}$ are adequate for the orthodontic practice (15). These results agree with values reported in the literature as clinically acceptable, since the mean values of fluoride-treated groups were higher than those recommended by the first study, whereas in the oral environment can be found bond strengths lower than those found in vitro (23).

ARI analysis showed predominance of failures at the enamel-resin interface in all groups, which is an unfavorable condition, because the shear force stress could increase the probability of damage on the structure of enamel during removal of orthodontic appliances (18). Also Kimura et al. (19), evaluating the effect of fluoride varnish, reported failures predominantly at the enamel/ resin interface, which might be attributed to a deficiency in the penetration of the adhesive into the enamel. Based on the ARI analysis, it was not possible to relate decrease of bond strength values with the ARI scores.

Considering the limitations of this study, it may be concluded that the treatment of enamel with $1.23 \%$ APF and 5\% SFV prior to bonding of orthodontic brackets reduced the shear bond strength, although the values obtained are within the strength limits accepted for most procedures performed in clinical orthodontics.

\section{RESUMO}

O objetivo deste estudo foi o de avaliar in vitro a resistência adesiva de bráquetes após o pré-tratamento do esmalte com diferentes soluções fluoretadas. Foram utilizados 48 incisivos bovinos hígidos recém-extraídos que foram aleatoriamente divididos em 4 grupos experimentais $(n=12)$. CG (controle): sem tratamento; FN: aplicação de flúor neutro por 4 min; FFA: aplicação de flúor fosfato acidulado (FFA) a 1,23\% por 4 min; e VFS: aplicação de verniz de fluoreto de sódio a $5 \%$ por $6 \mathrm{~h}$. Após o tratamento dos grupos, foi realizada a profilaxia do esmalte e os bráquetes foram fixados utilizando o compósito Transbond XT (3M), seguindo as especificações do fabricante. A resistência adesiva foi verificada através do teste de cisalhamento, realizado na Máquina de Ensaio Universal DL-2000 24 h após a fixação dos bráquetes. As superfícies dos dentes foram analisadas para verificação do índice de adesivo remanescente (IAR). Por meio dos testes estatísticos ANOVA e Tukey $(\alpha=5 \%)$, observou-se diferença estatisticamente significante entre os grupos estudados ( $p<0,0001$ ), sendo que GC e FN, apresentaram valores superiores de resistência adesiva quando comparados aos grupos FFA e VFS, porém GC-NF e FFA-VFS não apresentaram diferenças estatisticas entre si $(p>0,05)$. A análise dos escores do IAR revelou que grande parte das falhas ocorreram na interface esmalte-resina. Conclui-se que o tratamento do esmalte com FFA 1,23\% e VFS a $5 \%$, previamente à fixação de bráquetes ortodônticos, reduziu os valores de resistência adesiva ao cisalhamento.

\section{ACKNOWLEDGEMENTS}

This study was supported by the Foundation for Research and Scientific and Technological Development of Maranhão for the scientific initiation (BIC/FAPEMA - \#011/2011).

\section{REFERENCES}

1. Maxfield BJ, Hamdan AM, Tüfekçi E, Shroff B, Best AM, Lindauer SJ. Development of white spot lesions during orthodontic treatment: perceptions of patients, parents, orthodontists, and general dentists. Am J Orthod Dentofacial Orthop 2001;141:337344.

2. Marinho VC, Higgins JPT, Logan S, Sheiham A. Systematic 
review of controlled trials on the effectiveness of fluoride gels for the prevention of dental caries in children. J Dent Educ 2003;67:448-458.

3. Murakami C, Bönecker M, Corrêa MS, Mendes FM, Rodrigues CR. Effect of fluoride varnish and gel on dental erosion in primary and permanent teeth. Arch Oral Biol 2009;54:997-1001.

4. Almeida MQ, Costa OX, Ferreira JM, Menezes VA, Leal RB, Sampaio FC. Therapeutic potential of Brazilian fluoride varnishes: an in vivo study. Braz Dent J 2011;22:193-197.

5. Hirce JD, Sather AH, Chao EY. The effect of topical fluorides, after acid etching of enamel, on the bond strength of directly bonded orthodontic brackets. Am J Orthod 1980;78:444-452.

6. Santos L de M, Reis JI, Medeiros MP, Ramos SM, Araújo JM. In vitro evaluation of fluoride products in the development of carious lesions in deciduous teeth. Braz Oral Res 2009;23:296-301.

7. Chadwick BL, Roy J, Knox J, Treasure ET. The effect of topical fluorides on decalcification in patients with fixed orthodontic appliances: a systematic review. Am J Orthod Dentofacial Orthop 2005;128:601-606.

8. Kajander KC, Uhland R, Ophaug RH, Sather AH. Topical fluoride in orthodontic bonding. Angle Orthod 1987;57:70-76.

9. Damon PL, Bishara SE, Olsen ME, Jakobsen JR. Effects of fluoride application on shear bond strength of orthodontic brackets. Angle Orthod 1996;66:61-64.

10. Keçik D, Cehreli SB, Sar C, Unver B. Effect of acidulated phosphate fluoride and casein phosphopeptide-amorphous calcium phosphate application on shear bond strength of orthodontic brackets. Angle Orthod 2008;78:129-133.

11. Ganss C, Klimek J, Schaffer U, Spall T. Effectiveness of two fluoridation measures on erosion progression in human enamel and dentine in vitro. Caries Res 2001;35:325-330.

12. Aasende P, Depalola F, Brudevold F. Effects of daily rinsing and ingestion of fluoride solution upon dental caries and enamel fluoride. Arch Oral Biol 1972;17:1705-1714.

13. Choi S, Cheong Y, Lee GJ, Park HK. Effect of fluoride pretreatment on primary and permanent tooth surfaces by acidetching. Scanning 2010;32:375-382.
14. El Bokle D, Munir H. An in vitro study of the effect of Pro Seal varnish on the shear bond strength of orthodontic brackets. World J Orthod 2008;9:141-146.

15. Artun J, Bergland S. Clinical trials with crystal growth conditioning as an alternative to acid-etch enamel pretreatment. Am J Orthod 1984;85:333-340.

16. Thompson RE, Way DC. Enamel loss due to prophylaxis and multiple bonding/debonding of orthodontic attachments. Am J Orthod 1981;79:282-295.

17. Todd MA, Staley RN, Kanellis MJ, Donly KJ, Wefel JS. Effect of a fluoride varnish on demineralization adjacent to orthodontic brackets. Am J Orthod Dentofacial Orthop 1999;116:159-167.

18. Adanir N, Türkkahraman H, Yalçin Güngör A. Effects of adhesion promoters on the shear bond strengths of orthodontic brackets to fluorosed enamel. Eur J Orthod 2009;31:276-280.

19. Kimura T, Dunn WJ, Taloumis LJ. Effect of fluoride varnish on the in vitro bond strength of orthodontic brackets using a self-etching primer system. Am J Orthod Dentofacial Orthop 2004;125:351356.

20. Kim MJ, Lim BS, Chang WG, Lee YK, Rhee SH, Yang HC. Phosphoric acid incorporated with acidulated phosphate fluoride gel etchant effects on bracket bonding. Angle Orthod 2005;75:678684.

21. Meng CL, Li CH, Wang WN. Bond strength with APF applied after acid etching. Am J Orthod Dentofacial Orthop 1998;114:510-513.

22. Bishara SE, Chan D, Abadir EA. The effect on the bonding strength of orthodontic brackets of fluoride application after etching. Am J Orthod Dentofacial Orthop 1989;95:259-260.

23. Hajrassie MK, Khier SE. In-vivo and in-vitro comparison of bond strengths of orthodontic brackets bonded to enamel and debonded at various times. Am J Orthod Dentofacial Orthop 2007;131:384390.

Received August 16, 2012 Accepted November 30, 2012 